76 巻 766 号 (2010-6)

\title{
シリンジを用いたイレウスチューブのバルーン内圧制御*
}

関健 史 ${ }^{* 1}$, 長 縄 明 大*1, 岡

\section{Control of Balloon Internal Pressure for Ileus Tube Using a Syringe}

\author{
Takeshi SEKI*5, Akihiro NAGANAWA, Kiyoshi OKA, \\ Shinji ISHIKAWA and Junji YOSHINO
}

${ }^{* 5}$ Faculty of Engineering and Resource Science, Akita University, 1-1 Tegatagakuen-cho, Akita-shi, Akita, 010-8502 Japan

\begin{abstract}
Recently, by development of double balloon and capsule endoscopes, small intestinal whole area observation was enabled. However, it is difficult to use these endoscopes in patients with intestinal obstruction and adhesion. We developed a new endoscope that can be used in patients with intestinal obstruction and adhesion; this instrument consists of an ileus tube and an optical fiberscope (diameter, $1.1 \mathrm{~mm}$ ). The complete observation of small intestinal is to be planned by controlling internal pressure of balloon in ileus tube, and pulling the tube out at constant speed. In our previous study, we have developed an internal pressure control device which consists of a balloon of ileus and an industrial cylinder, and we confirmed the utility. In this study, we developed a new control device combined with a general medical syringe, which enables to be sterilized easily and aiso to give less anxiety to patients. As the results of performance experiment of the device, the control accuracy was within $\pm 0.5 \%$ error. Furthermore, in a disturbance response, the pressure fluctuation was limited down to $12 \%$, compared with a case without any control.
\end{abstract}

Key Words : Medical and Welfare Assistance, Mechatronics, Digital Control, Small Intestine, Ileus Tube, Balloon Internal Pressure

\section{1. 緒言}

小腸は, ダブルバルーン内視鏡やカプセル内視鏡に よって全域検査が可能となり, 各種小腸疾患の診断に 用いられているが, 癒着や狭窄が存在するイレウス症 例では，使用が制限されることが多い(1)(2).

一方, イレウス症例の治療法として, イレウスチュー ブを用いた方法があり，患部の腸液や消化物をチューブ 先端部の側孔より吸引して排出治療する.このチュー ブ内は, 著者らが開発した外径 $1.1 \mathrm{~mm}$ の極細径光ファ イバスコープを通すことができるため, イレウスチュー ブと光ファイバスコープを組み合わせ，イレウス症例 の患者にも適用できる小腸内視鏡に関する研究開発を 行っている.この特徵は, イレウス症例の治療のため

\footnotetext{
* 原稿受付 2009 年 12 月 15 日.

*1 正員, 秋田大学工学資源学部 (五010-8502 秋田市手形学園 町 1-1).

*2 正員, (独) 日本原子力研究開発機構 (严319-1195 茨城県那 珂郡東海村白方白根 2-4).

*3 秋田大学工学資源学部。

*4 藤田保健衛生大学坂文種報徳會病院内科( $3454-8509$ 名古 屋市中川区尾頭橋 3-6-10)

E-mail : seki@ control.mech.akita-u.ac.jp
}

に既に挿入されているチューブをそのまま用いるため, 内視鏡㨂入に伴う苦痛はほとんどなく，消化管穿孔や 腸管損傷の危険も低いことが挙げられ，イレウス解除 直後の病変部の観祭や手術適用の判断などに用いるこ とが期待されている。これまで行った臨床試験では, チューブ先端部付近の観察は可能であったが，それ以 外の場所の観察はできていない ${ }^{(3)}$.

そこで,イレウスチューブのバルーン内圧を一定值 に保持しながらチューブと光ファイイ゙スコープを同時 に引き抜き，挿入時に手繰り寄せられた腸管を一定の 速度で開放し，チューブ先端部より口側の腸管内を観 察するためのバルーン内圧制御装置を開発した ${ }^{(4)}$. 本 装置の有効性を確認するため，製作したシリコン製腸 管モデル内にチューブを挿入して行った引き抜き試験 により，外部圧力の影響を抑制してバルーン内圧を一 定值に保持することができたため，実際の臨床でも腸 管を一定の速度で開放できる可能性があることを確認 した。

しかし，工業用の水圧シリンダを使用したため，シ リンダ本体の滅菌性や容量過多の問題だけでなく，患 
者へ不安感を与える恐れが懸念される. 本研究では, 医療シリンジを用いたバルーン内圧制御装置を製作し, その制御性能を検証した。

\section{2. バルーン内圧制御装置の概要}

図 1 にシリンジを用いたバルーン内圧制御装置を, 図 2 にその構成を, 表 1 に使用した主な部品の仕様を 示す. イレウスチューブは, 先端部に 2 つのバルーン を有する親水性イレウスチューブ $16 \operatorname{Fr}$ (クリエイトメ ディック)を用いた. このチューブの前方バルーンへ滅 菌蒸留水を注入するための一方弁に三方活栓を接続し, さらにシリンジと圧力センサを接続した. 圧力センサ は, バルーンに加わる圧力值を計測し, $\mathrm{AD}$ 変換器を 介して PC内にデータが取り込まれる. PC内では, 一 定の内圧值を保持するための演算が行われ, DA 変換 器よりモータドライバに駆動電圧を出力する. シリン ジ内には, 末端の円形部分がスライダと固定されたプ ランジャが挿入されており, PCからの指令に応じて

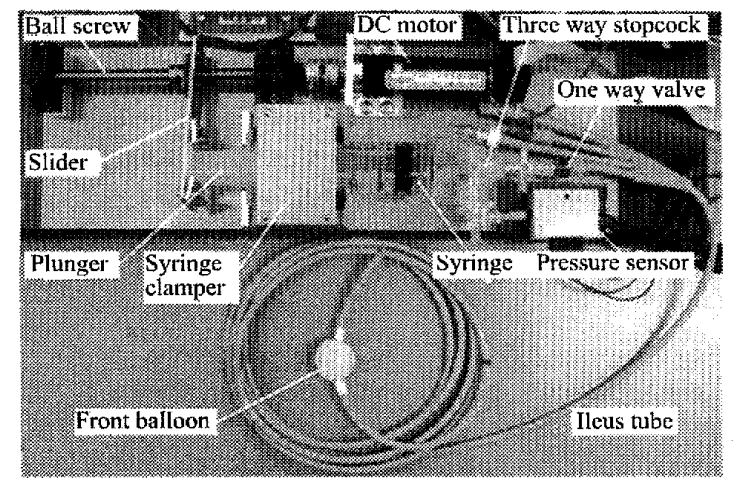

Fig. 1 Balloon pressure control system using a medical syringe

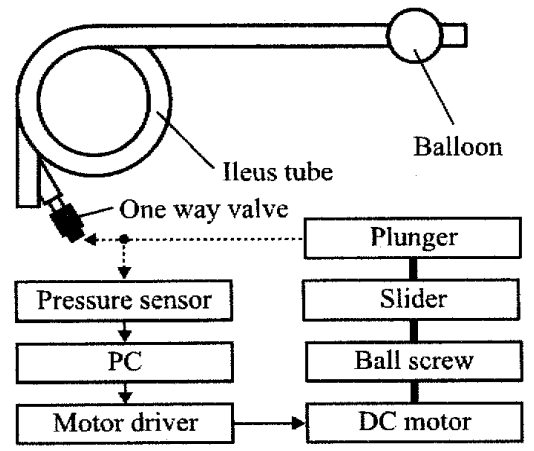

Fig. 2 Composition of control system

Table 1 Specification of parts

\begin{tabular}{|l|l|}
\hline Syringe & $50[\mathrm{ml}]$ (Terumo) \\
\hline Sensor & XFHMC-050KP (Fujikura) \\
\hline DC motor & RE25 (Gearhead GP26B, Maxon) \\
\hline Ball screw & BNK0801-3(THK) \\
\hline AD/DA convertor & ADA16-8/2(CB)L (Contec) \\
\hline
\end{tabular}

駆動されるモータとボールネジによりプランジャが動 作し, バルーン内圧を加減する. 実験では, バルーン 内に約 $10 \mathrm{ml}$ の水を注入し定常圧力值が約 $15 \mathrm{kPa}$ と なった状態を初期状態とした.

\section{3. 制 御 系 設 計}

バルーン内圧制御系の仕様は，(1) 医師が腸管把持 の状態を確認しながら, 定常值を変更するための目標 值応答特性と, (2) 腸管内のバルーンが腸管径の変化 による内圧変化や, 蠕動運動などの小腸の動きに対す る内圧変化を抑制し，一定の内圧值を保持するフィー ドバック特性が要求される. このため, 条件付き 2 自 由度制御系を採用した ${ }^{(5)}$.

制御対象のモデル $P(s)$ は, ステップ応答の波形か ら求めた. 図 3 にステップ応答を示す. なお, 圧力セ ンサの測定範囲が $50 \mathrm{kPa}$ までであるので, 測定は 45 $\mathrm{kPa}$ までとした. 時刻 0.2 秒からモータドライバに 0.5 Vの電圧を印加し続けると, モータが一定速度で回り 続けるため, 時間の経過と共に圧力值は大きくなった. このため, モデル $P(s)$ を次式とした.

$$
P(s)=\frac{200}{s+1.25} \cdot \frac{1}{s}
$$

また, 目標值応答特性を決定する規範モデル $F(s)$ は, 本研究と並行して行っている小腸内圧計測の踟床結果 (藤田保健衛生大学の倫理委員会で承認) より, 過度に 立ち上がり特性を速くすることなく変更するため, 次 式とした ${ }^{(6)}$.

$$
F(s)=\left(\frac{1}{s+1}\right)^{2}
$$

さらに, フィードバックコントローラ $C(s)$ は, 不完 全微分型 PID コントローラとし, 各ゲインは試行錯誤 により決定した.

$$
C(s)=0.2+\frac{0.25}{s}+\frac{0.5 s}{s+10}
$$

実験では, 式(1)〜(3) をサンプリング周期 $50 \mathrm{msec}$ で 離散化して PC 上に実装した.

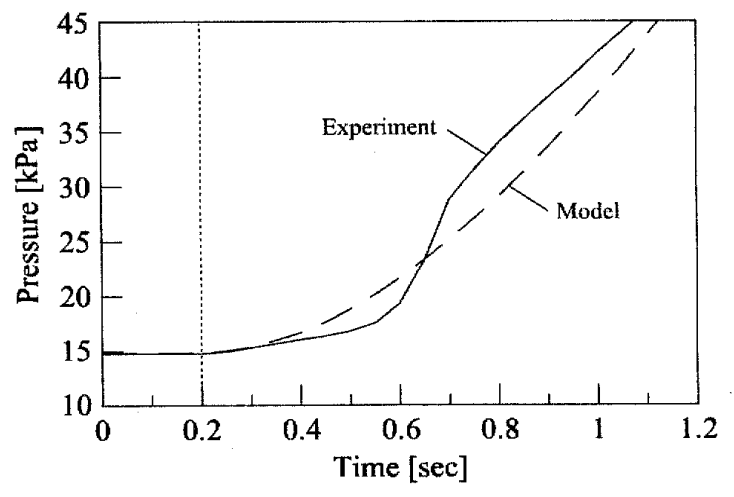

Fig. 3 Step response of plant 


\section{4. 制御性能の検証}

\section{$4 \cdot 1$ 目標值応答特性 図 4 亿目標值応答の結果} を示す. 目標值は, 時刻 5 秒の時, 内圧変化の臨床結 果を参考に $15 \mathrm{kPa}$ から $2 \mathrm{kPa}$ 変化させた. 図より, バ ルーン内圧は，規範モデルの出力にほぼ一致しており， 目標值 $17 \mathrm{kPa}$ に到達後も $\pm 0.5 \%$ 以内の精度で目標圧 力を保持することができた.

4.2 外乱抑制応答 図 5 に外乱抑制応答の結果 を示す. 外乱は, その大きさが臨床結果の内圧変化を 参考にし，バルーンに一定荷重をステップ状に与えた. 制御を行わない場合 (三方活栓を切り替え，シリンジ 側に内圧変化が伝達しない状態) では, 最大 $4.22 \mathrm{kPa}$ 変化した. 一方, シリンジを用いた制御の場合では, 最大約 $0.5 \mathrm{kPa}$ の内圧変化となり, 制御を行わない場 合と比べると約 $12 \%$ の変化となり，非常に効果的に 外乱の影響が抑制された．また， $\pm 2 \%$ 以内の定常状 態に戻るまでの時間は約 1.5 秒であり，臨床の内圧変 化と比較しても，無理に抑制しようとはしておらず, 良好な結果が得られた。

以上の結果より, バルーン内圧を一定值に保持する ことができ，一定の速度で引き抜ける可能性があるこ とがわかった.

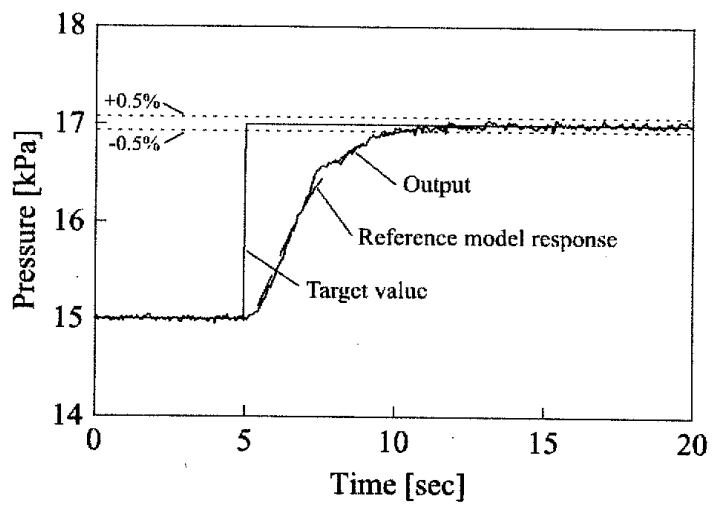

Fig. 4 Reference response property

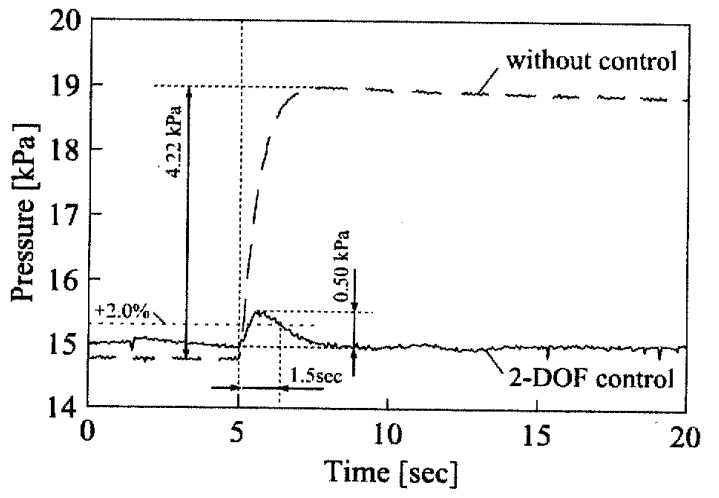

Fig. 5 Disturbance refection property

\section{5. 結論}

本研究では, イレウス症例の患者にも適用できる小 腸内視鏡を開発する目的で，医療シリンジを用いたバ ルーン内圧制御装置を製作し，その制御性能の検証を 行った. その結果, 目標值応答, 外乱抑制応答ともに, 小腸内圧計测の臨床結果と比較考察すると，適切に制 御できる結果が得られた.

\section{謝辞}

本研究は平成 19 21 年度文部科学省科学技術振興 調整費「光医療産業バレ一拋点創出」の一環として実 施したものである．関係者各位に謝意を表する．また， 本システムを製作するにあたりご協力して頂いた株式 会社フジクラ, およびエーテック株式会社の関係者に 謝意を表する。

\section{文献}

(1) Yano, T. and Yamamono, H., Characteristics and Insertion Procedure of the Double Balloon Endoscopy, The Japan Society of Coloproctology, Vol. 60, (2007), pp.940-946.

(2) Iddan, G., Meron, G., Glukhovsky, A. and Swain, P., Wireless capsule endoscopy, Nature, Vol. 405, (2000), pp.417.

(3) Naito, T., Yoshino, J., Inui, K., Wakabayashi, T., Kobayashi, T. and Watanabe, S., Clinical Application of Ultra-small-caliber Enteroscope for Ileus, Clinical Gastroenterology, Vol. 23, No. 2, (2008), pp.277-280.

(4) Seki, T., Takei, N., Naganawa, A., Oka, K., Yoshino, J., Design of balloon pressure control system for ileus tube, Joint Conference of Engineering Applications on Wellbeing and Life Support, (2008), pp.154.

(5) Sugie, T. and Fujita, M., "Introduction to Feedback Control", Corona Publishing, (1999).

(6) Ishikawa, N., Oka, K., Naganawa, A., Yoshino, J., Wakabayashi, T., Watanabe, S. and Naito, T., Development of an Instrument System for Measuring the Internal Pressure of the Small Intestine Using an Ileus Tube, Transactions of the Japan Society of Mechanical Engineers, Series C, Vol. 75, No. 756, 2009, pp.2359-2362. 